\title{
Study on Project Teaching Reform and Practice of Quality Engineering Curriculum in University
}

\author{
Zhou Yuqing \\ College of Mechanical \& Electrical Engineering \\ Wenzhou University \\ Wenzhou, China \\ e-mail: zhouyq@wzu.edu.cn \\ Gao Chen \\ College of Mechanical \& Electrical Engineering \\ Wenzhou University \\ Wenzhou, China \\ e-mail:137705927@qq.com
}

\author{
Zhou Hongming \\ College of Mechanical \& Electrical Engineering \\ Wenzhou University \\ Wenzhou, China \\ e-mail: 391029785@qq.com \\ Pang Jihong \\ College of Mechanical \& Electrical Engineering \\ Wenzhou University \\ Wenzhou, China \\ e-mail: jhpang@126.com
}

\begin{abstract}
According to the characteristics of quality engineering curriculum and shortcomings of traditional teaching methods, this paper studies on project teaching reform and practice of quality engineering curriculum, for improving students' quality engineering core skills. An implementation framework of the project teaching of quality engineering curriculum is set up, the process of implementation is combed, the project design elements and standards are detailed, and an assessment method combined the study process with result is set. Teaching practice shows that students can have a good grasp of the mainly knowledge and methods, and greatly improve their learning enthusiasm and initiative in quality engineering curriculum, when taught by project teaching.
\end{abstract}

Keywords-quality engineering; project teaching; implementation framework; project design; assessment method

\section{INTRODUCTION}

"Quality Engineering" is a backbone of industrial engineering courses and also a stronger course in theory and practice. Studied this course, students can understand nowadays' development and hot issues of quality management, analyze the working principle of quality management in product design and production processes practically, grasp the basic theory, methods and tools of quality control and quality improvement, improve the working and innovative ability to analyze and solve the actual quality problems.

With the development of economic globalization, the competition of quality is increasing. The level of quality management and product quality has become the most crucial factor in the survival of companies [1-3]. However, there is still a large gap between most Chinese companies and developed countries' companies in management idea and management specification. The main reason is the lack of quality management personnel who knows the management and project well. Therefore, completing the teaching of quality management course that cultivates the practice ability has a great significance for cultivating students' ability to solve practical problems and innovation practice. To overcome drawbacks of the traditional teaching methods in the quality engineering curriculum this paper introduces the project teaching method to explore and discuss about teaching reform and practice of quality engineering curriculum, to provide a reference for teaching reform in Teaching Quality Management courses.

\section{MAIN PROBLEMS EXISTING IN TEACHING}

People who engage in quality management require a strong logical thinking and analytical reasoning skills, must have excellent knowledge in workmanship and manufacturing process, able to read drawings, various standards and inspection files, can operate and use test tools and equipment, will work out inspection rules and quality standards, and can seize the key problem to develop effective corrective actions with the use of quality tools expertly. Quality engineering personnel without these professional knowledge and skills will not adapt to the needs of work well. However, influenced by the traditional educational concepts, teachers usually pay more attention to theory and knowledge but ignore practice and ability. Students are difficult to directly apply what they learnt to engineering practice, and lack of innovation ability. That is the mismatch between what schools are producing and what companies need [4].So traditional "quality engineering" teaching way exists some problems [5,6]:

(1) Emphasis on theoretical knowledge too much: Teachers always follow the script in the class that causes students receiving knowledge passively. Some teachers even change the quality engineering curriculum into a statistics course with too much teaching statistical methods and ignore its practical application. At the same 
time, because of the characteristics of the course, there are many specialist terms and abstract concepts and many nouns directly translated from foreign standard. It will not stimulate students' interest in learning and even lead to students to produce fear emotion to this course.

(2) Single teaching method. Teachers in many universities are directly from students to teachers, without practical experience and training of the quality engineering in companies. It leads that teachers adopt single teaching form that theory and practice are uncombined, which lead students learned difficultly and could not reach requirements in professional ability. So the result of learning and teaching for students is far from ideal.

(3) Less practice. Many schools do not offer quality engineering curriculum experimental class, or have experimental classes but the content is old or too simple. That will not reach the purpose of developing students' practical ability and practical skills, and unable to meet the requirements of the employer.

\section{PROJECT TEACHING REFORM}

\section{A. The Meaning of the Project Teaching}

Project teaching aims to train students' practical ability to complete practical tasks professionally. It is a teaching model that is to complete a specific and complete task by students, and finally obtain a "product" with actual value $[7,8]$. In the implementation process, according to the knowledge content built on the subject system, the course is divided into a number of techniques or skill units and each unit as a teaching project. On the premise of "project", to meet the requirements of professional positions, teacher can take students as the main body to design and complete the units. The quality of "product" completed by students is used to evaluate whether they attain the teaching objective or not.

\section{B. Key Problems in the Implementation of the Project Teaching Method}

The template is used to format your paper and style the text. All margins, column widths, line spaces, and text fonts are prescribed; please do not alter them. You may note peculiarities. For example, the head margin in this template measures proportionately more than is customary. This measurement and others are deliberate, using specifications that anticipate your paper as one part of the entire proceedings, and not as an independent document. Please do not revise any of the current designations.

\section{1) Changes in teaching methods and requirements}

Because of the traditional teaching methods that teachers only teach students the knowledge, most students generally have become accustomed to the learning style that accept knowledge passively. But when the project teaching method is used in quality engineering curriculum, students will be asked to learn actively. Students must face the project, and then to find the information they needed to solve the problem by themselves, to explore ways and methods to solve the problem and aware of their role in their team, which is undoubtedly a huge challenge for students. Teachers should do their best to make students understand the significance of the project teaching. When students encounter problems, teachers should give guidance in time. When students are doing the project, they will meet different difficulties. Some difficulties even have not been met before for teachers. So teachers in project teaching must have a broad knowledge and skilled skills, and also need to spend more time and effort than traditional teaching way.

2) Operation of related equipment and software during project implementation

It needs some related equipment and software when project of quality engineering is implemented. As for equipment, for example, to do well quality function deployment (QFD) projects, teachers should select some product which could be obtained conveniently and be understood easily by students. To do well parameter design projects, some appropriate product test equipment is needed. To do well process quality control projects, some processing equipment and relevant materials are essential. Teachers can consider these equipments based on the actual situation in their college. As for software, it needs one or more statistical software, such as Minitab, Excel, SPSS, etc.

\section{3) To create a study atmosphere for project teaching}

Project teaching method emphasizes learning autonomously and learning in groups. Furthermore, students are actively involved in the implementation of the project. Therefore, teachers should create a relaxed learning atmosphere of democracy and freedom to stimulate students' interest in learning and ability to work in teams.

\section{CONSTRUCTION OF THE PROJECT TEACHING METHOD OF QUALITY ENGINEERING}

\section{A. The Implementation Framework of the Project Teaching}

The reform of the teaching method of quality engineering curriculum aims to enable students to have the ability of quality management and quality improve, to master the theory related to quality management, and also to link theory to practice. Furthermore, it also aims to enable students to raise interest in learning, and change passive learning to active exploratory learning. Specific implementation framework is shown in Fig 1. In theory, with Total Quality Management and Six Sigma management theory as a guide, quality engineering curriculum is divided into three modules: Quality Design, Quality Control and Quality Improvement. And each module contains a number of key knowledge points. For example, the Quality Design module contains Quality Function Deployment, Kano Model, Taguchi Design, FMEA and some other knowledge points. Besides, the Quality Control module contains Control Chart, Process Capability Analysis, Histogram and some other knowledge points. And the Quality Improvement module contains Design of Experiment, ANOVA, Correlation Analysis, Regression Analysis and some other knowledge points. Each module can be designed several projects to be completed by students. Knowledge involved in the project can be determined according to regional characteristics of the industry as well as teachers' personal level. Finally, if time permitted, teachers can also pull the contents of the three modules together to design a comprehensive Six 
Sigma project, what allows students to practice the implementation of a complete quality project. The implementation framework is basically followed by the explanation from engineering example to theoretical knowledge, and then based on the students, through the implementation of engineering project, to deepen students' understanding of knowledge in practice, finally return to the theoretical knowledge to explain such a teaching process. In such a process, teaching always develops center on the project, so the student to learn what is needed in the project and to do what must do in the project.

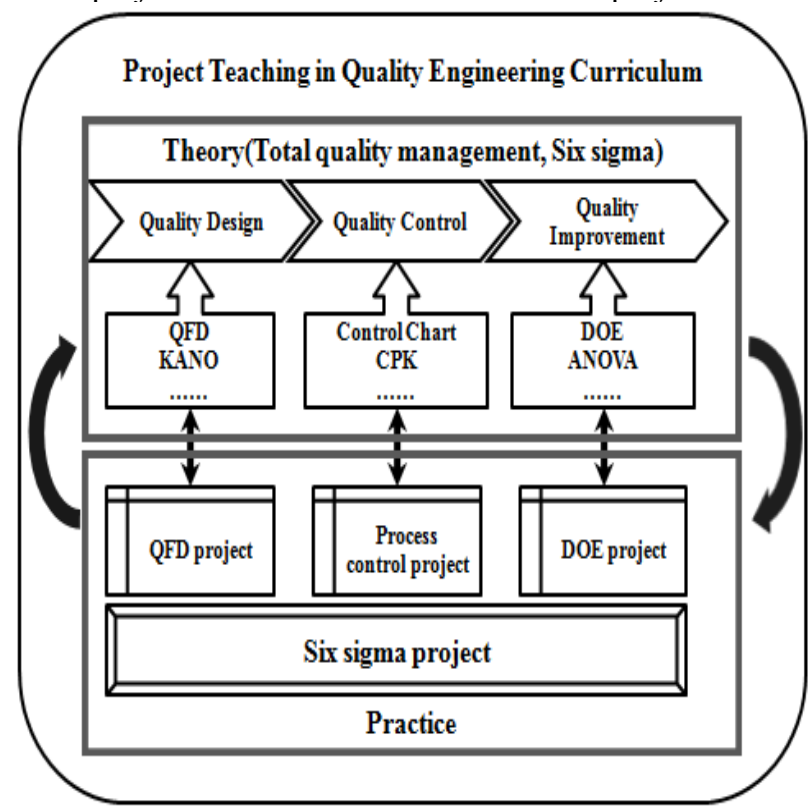

Figure 1. The implementation framework of the project teaching of quality engineering

\section{B. Project Design}

In the project teaching, the design of the project is the most critical aspects. On the one hand, the difficulty of the project should be moderate, if the project is designed too simple, it can't serve the purpose of training students, but if the design is too complex, it will blow the students' enthusiasm. On the other hand, the project must be spread out around about one core of knowledge, can't deviate from the purpose of teaching. Therefore, when projects are designed, teachers need to clearly define the criteria for each project. And the project standards include learning areas, skill focus, key question, the study subject, the final product, the main task and extend skills and so on. Tab 1 take the QFD project as an example to illustrate the project standards.

\section{Process of the Project Teaching Method's Implementation}

The teaching of quality engineering curriculum contains the teaching content when design projects of QFD, parameter design, production processes control (and so on), learn the knowledge, foster the quality processing power, train software skills when implement projects. Then students will really be "learning by doing, doing by learning" to improve their practical ability and ability to solve problems in the implementation of projects. The project teaching method's implementation steps are as
TABLE I. EXAMPLE OF PROJECT STANDARD

\begin{tabular}{|c|c|}
\hline Project Name & QFD Project \\
\hline Learning Areas & Quality Design \\
\hline Skill Focus & Quality Function Deployment \\
\hline Key Question & $\begin{array}{l}\text { How to transform the customers' requirements } \\
\text { into product features }\end{array}$ \\
\hline Study Subject & Table fan \\
\hline Final Product & Main features table of the table fan \\
\hline Main Task & $\begin{array}{l}\text { The project allows students to identify the main } \\
\text { features of the table fan when they use QFD } \\
\text { method to transform the customers' requirements } \\
\text { into table fan's features. The project includes } \\
\text { identifying customer needs, features } \\
\text { decomposition, requirement and function } \\
\text { correlation analysis, importance calculation and } \\
\text { some other steps. }\end{array}$ \\
\hline Extend Skills & KANO Model, Analytic Hierarchy Process \\
\hline
\end{tabular}

follows:

- Students search for project-related information independently, analyze the project, familiarize the basic requirements of the project and find knowledge points required for completing the project in groups.

- Teachers explain knowledge points and abilities related to the project, and can hire relevant technologist to explain methods of implementing the project when there is an opportunity.

- Under the guidance of teachers, each group makes a project implementation plan, then divides the project within the group and implements the project according to plan, finally writes and improves the project report.

- Each project requires each group to prepare a PPT presentation and report their group's project situation on stage. Teachers organize 3-5 reviewers (including teachers and technical personnel of enterprises) to comment on the advantages and disadvantages of the project for each group, which consolidates students' theoretical knowledge and improves their engineering capabilities.

\section{Examination Forms}

The traditional way of examination forms is resultsoriented, mostly using the following examination forms: grades + experiment scores + final test scores. Such examination forms for the assessment of teaching process are less involved. And in the process assessment, regular attendance, assignment layout, group discussions and other examination forms still focus on results. It's not conducive to examine students' practical skills, and not adapt to project teaching model and its learning process assessment $[9,10]$. Moreover plagiarism occurs more easily. According to the practical features of project teaching, changing the results-oriented assessment into the process assessment and emphasizing the practical operation and professional core skills are necessary for examination forms. 
Specific examination forms can refer to the followings:

- Grades (20\%): The grades evaluate on the basis of attendance, homework and so on.

- $\quad$ Project Training (40\%): The examination forms of project training consist of two parts. First, team work is as a process assessment unit, including the implementation of project progress, knowledge, understanding of the logical relations between projects, using of proper methods, rationality of the project results, defense performance and so on. And foci of the team assessment are correctness and accuracy of the completion of project. The second is based on order relation analysis (ORA) method for students' individual performance assessment. It adopts the method that team members rate each other's contributions. And it requires students to sort other team members' contribution in completing the project. According to the rule of the ORA method, decide each team member's relative contribution score. Then, calculate each team member's average contribution score. Finally, team process assessment scores as a benchmark, weighted team members eventually personal scores of the project training evaluation.

- Final Test Scores ( 40\%) : Finish the exam within the stipulated time using closed book, and the exam scores is student's final test scores.

The integrated examination forms not only multi-angle, fairly and objectively evaluate the effect on student learning, but also urge students to actively integrate into the team, learn together to explore, to contribute to the completion of the project.

\section{CONCLUSIONS}

The project teaching breaks the limitation of traditional teaching methods. Compared to traditional class teaching, project teaching has some advantages as the following:

- In terms of access to knowledge, students from the original passive learning converted into active, enhance their practicability and purpose of obtaining knowledge.

- From teachers teaching, teaching methods change instilling into guiding. On the one hand, allows students to take the initiative to find projects and learn something from it, which stimulates students' desire to learn actively. On the other hand, teachers as the key factors to ensure the success of the project teaching, should have higher requirements, need to be a better guide.

- From imparting knowledge system, project teaching changes the imparting knowledge and skills way from the original unit by unit into integration of various knowledge. And when students complete the project they combine the basic knowledge, which increase the students' memory of the theory knowledge.

- $\quad$ Project teaching has a unique way of education. It is conducive to practice students' professional ability, to develop students' creative ability, and to cultivate creative talents for quality engineering.

\section{REFERENCES}

[1] Mu Guangyu, Xue Dongjuan, Pan Lanlan. Study on Teaching Reform of Quality Management for Practice Capacity Training[J]. Equipment Manufacturing Technology, 2013(5): 227-231.

[2] Steve Williams. 21st Century Quality Management and Good Managemen. Woodhead Publishing Ltd, 2014

[3] David L. Goetsch. Studyguide for Quality Management for Organizational Excellence: Introduction to Total Quality, Cram101 Incorporated, 2013

[4] Zhang Fuying, Zheng Hui,Meng Yanhong, Xue Qiang, Ma Chen An Experiencing Teaching Model for the Course of Quality Management and Reliability[J]. China Education of Light Industry, 2013(2): 71-74.

[5] Xie Zhengyi. Research of Teaching Reform of Quality Inspection and Quality Management Based on Ability-oriented[J]. Mechanical Management and Development, 2013(6): 164-167.

[6] Zou Xiaoyan. Teaching Reform of Quality Management Curriculum[J]. Mechanical Career Education, 2008(6): 58-59.

[7] Guo Fanbo, Qiu Zhanhong. Research on Project Type Teaching of Engineering Survey[J]. Bulletin of Surveying and Mapping, 2014( 6) :128-130

[8] Wang Xinliang. Cognition and Suggestions on Project-based Teaching[J]. Journal of Tianjin Vocational Institutes, 2013,15(8): 117-119.

[9] Russell, Anthony. Making the Most of Teaching Assistants: Guidance for All Schools Managers and Leaders. Macmillan Publishers NZ, 2013.

[10] Peng Rongli. Exploration of Evaluation System of Learning in Project Teaching[J] Journal of Hunan Industry Polytechnic, 2013,13(2): 90-91. 